\title{
Between Economic Utility and Regional Attachment: The EMU and Eastern Enlargement in the Spanish Eye
}

\author{
Susanna Kislenko
}

\begin{abstract}
This paper uses Spain as the case study in furthering understanding of the forces that influence public opinion, specifically as they exist within the contemporary European context. To evaluate this, the focus is on two primary issues: the European Monetary Union (EMU) and the Eastern Enlargement. In order to explore the relationship between opinions towards EU membership, the Euro and support for enlargement, ordinary least squares (OLS) and logistic multivariate regression methods are used to model public opinion development. The argument put forth in this paper is that the formation of public opinion is influenced by both regional dynamics and utilitarian economic considerations. Within this framework, the concept of political symbolism is explored in uncovering the influence of cognitive mobilization, group attachment and cost-benefit factors as they relate to Spanish opinion on widening and deepening of the European Union.
\end{abstract}




\section{Introduction}

"The only feeling that anyone can have about an event he does not experience is the feeling aroused by his mental image of the event. That is why until we know what others think they know, we cannot truly understand their acts."

- Walter Lippmann (Public Opinion, 13)

It has been widely acknowledged that at its onset, the European integration project was primarily elite-driven, lacking active engagement of the general public. As a result, during the early stages of unification, there existed a consensus among political scientists and sociologists that the study of public opinion was not entirely relevant to the analysis of the European Community (EC), which would later become the European Union (EU). Now at the forefront of the $21^{\text {st }}$ century, as the EU celebrates its silver anniversary, there is a palpable need to study the development and evolution of public opinion in order to better understand the mechanics of European integration and align the interests of the general public with those of political elites.

The intention of this study is to further understanding of the dynamics of public opinion, specifically as it exists within the contemporary European context. Spain is employed as the case study in evaluating the factors that have exhibited the greatest influence on the formation of opinion about key matters related to European unification. More specifically, this project is an analysis of the structure of policy attitudes on two primary issues around which the Spanish public began to formulate strong views and which they saw as reflection of EU membership and European integration in the larger sense. The first of these is the European Monetary Union (EMU), arguably the most 
ambitious deepening attempt to date, with the second issue being the Eastern Enlargement. $^{1}$

The Spanish lens is an interesting one through which to view the Eastern Enlargement. Paralleling the present position of many Eastern European countries, when Spain first entered the EC in 1986, the country was politically isolated on the continent and viewed EC membership as its ticket back into the exclusive club of Western Europe. As Juan Díez Medrano explains, "In Spain, the EU has been represented as an opportunity to modernize the country and to break with Spain's secular isolation.”2 This study will illustrate that this understanding has framed much of Spanish public opinion on the EU, specifically as it applies to widening and deepening of the Union.

The paper begins with a review of the existing literature on public opinion and its foundations within the European context. The second section discusses the regional and socioeconomic dynamics that influence opinion formation in Spain. These messages are then compared to the individual-level variables that affect public opinion on the EMU and the Eastern Enlargement, which are evaluated using ordinary least squares (OLS) and logistic multivariate regression analysis of Eurobarometer Study $58.1^{3}$, in sections three and four. The discussion and conclusions follow.

\footnotetext{
${ }^{1}$ In 2004, ten new countries were admitted into the EU: Cyprus, the Czech Republic, Estonia, Hungary, Latvia, Lithuania, Malta, Poland, Slovakia and Slovenia. Bulgaria and Romania joined in 2007.

2 Juan Díez Medrano, "Democracy, Legitimacy and the European Union," in A European Public Sphere: How much of it do we have and how much do we need? (Amsterdam: Network of Excellence CONNEX and The Amsterdam School of Communications Research ASCoR, 2005), 4.

${ }^{3}$ At times referred to as "Study 58.1 " or simply “58.1” in this paper.
} 


\section{Section 1: Existing Knowledge about European Public Opinion}

Due to the fact that public opinion was not considered important or even relevant to the European integration project in its infancy stages, it was only over the last thirty years that this branch of political and sociological study began to surface in the European context. European scholars, however, did not need to start from scratch as studies about the North American public provided European theorists with a starting point in examining public opinion patterns. ${ }^{4}$

In contrast to the North American debate however, within the European sphere, there has been much less deliberation about whether or not public opinion has the potential to be stable and 'rational' over time. Rather, much of the work in this area has been focused on the factors that exert the strongest influence on the formation of opinion patterns. In reviewing European literature about public opinion formation, the primary groupings of ideas can be classified into four categories: political awareness, elite influence, economic utilitarianism and group/regional identities.

The political awareness ${ }^{5}$ hypothesis was first explored by Philip Converse in the United States. ${ }^{6}$ Within the context of European integration, this is explained through the understanding that since a great deal of the information presented about the European Union is fairly abstract for the average person, well-developed cognitive skills are required for a sound understanding of the concepts in order to formulate opinions on the issue. Linked to this is the idea that increased exposure to an issue and its various facets

\footnotetext{
${ }^{4}$ Rooted primarily on the work of such scholars as Walter Lippmann, Gabriel Almond, Philip Converse and, more recently, Benjamin Page and Robert Shapiro.

${ }^{5}$ Also known as cognitive mobilization.

${ }^{6}$ Converse built upon much of Almond's work in distinguishing between elite and mass beliefs. However, in contrast to Almond's emphasis on education as a key predictor of opinion patterns, Converse focused on political involvement as the primary source of distinctions between opinion groups. For more info, see Philip E. Converse, "The Nature of Belief Systems in Mass Publics," in Ideology and Discontent, ed. David E. Apter (New York: The Free Press, 1964).
} 
leads to greater familiarity with the subject and a deeper understanding of the broader consequences of particular policies. ${ }^{7}$

According to Inglehart, the more educated groups in society (who can be classified as elites), are the agents who trigger the dispersion of public opinion and orientations related to remote issue areas. ${ }^{8}$ Within this framework, there exist two explanations about how elite and mass opinions are tied together. The first of these, known as the push model, describes how the public "pushes” elites into certain actions or activities by emphasizing the importance of modernization, value change and cognitive mobilization. ${ }^{9}$ On the other side, the pull model, explains how elites "pull” the public into accepting and supporting their ideas.

The theory of economic utilitarianism, an understanding shaped by Matthew Gabel, is based on the idea that each tendency of opinion on a particular issue is essentially a costbenefit analysis of what the individual stands to gain from the particular policy choice. Economic utilitarianism uses the rational-choice framework to explain that as EU citizens in different socio-economic situations experience distinct costs and benefits from integrative policy, their support for EU integration is directly linked to their perceived welfare gains. It has been shown that economic factors, particularly perceived personal

\footnotetext{
${ }^{7}$ For more on this, see Lauren M. McLaren, Identity, Interests and Attitudes to European Integration (New York: Palgrave MacMillan, 2006), 14.

${ }^{8}$ Ronald Inglehart and Jacques-Rene Rabier, "Economic Uncertainty and European Solidarity: Public Opinion Trends," Annals of the American Academy of Political and Social Science 440, no. Nov. 1978 (1978): 139.

${ }^{9}$ Oskar Niedermayer and Richard Sinnott, eds., Public Opinion and Internationalized Governance (New York: Oxford University Press, 1995), 137.
} 
material benefits from EU membership, do play an important role in the formation of public attitudes towards the EU. ${ }^{10}$

Group identities have also been proven to be extremely important in influencing opinion formation. In the European context, this line of thinking is related to work by Michael Hechter who argues that “the greater the actor's dependence on the group, the more likely he is to comply with its obligations." ${ }^{11}$ In the case of the EU, there is an additional layer of analysis because of the regional and sub-regional dimensions.

Building upon the work of pioneers of public opinion study such as Lippmann and Converse, a new area of understanding has recently surfaced as an amalgamation of political, sociological and psychological understandings of the way in which public opinion is formed. As John Zaller points out, “every opinion is a marriage of information and predisposition: information to form a mental picture of the given issue and predisposition to motivate some conclusion about it."12 The information in question comes from the world external to the individual and in large part rests with the media messages that exist within the reference groups that the individual trusts.

\section{Section 2: Structure of Spanish Policy Attitudes}

It has been shown that in Spain, it is often the seemingly specific matters - such as suppressing the letter $\tilde{n}$ from the alphabet or banning bull-fighting - that matter in

\footnotetext{
${ }^{10}$ Vincent A. Mahler, Bruce J. Taylor, and Jennifer R. Wozniak, "Economics and Public Support for the European Union: An Analysis at the National, Regional and Individual Levels," Polity 32, no. 3 (2000): 447.

${ }^{11}$ Michael Hechter, "A Theory of Group Solidarity," in The Microfoundations of Macrosociology, ed. Michael Hechter (Philadelphia: Temple University Press, 1983), 21.

12 John Zaller, The Nature and Origins of Mass Opinion (Cambridge: Cambridge University Press, 1992), 6.
} 
driving opinions about the EU. ${ }^{13}$ The reason for this is linked to political symbolism; these symbols have an emotional, symbolic representation of an individual's identity, especially in those regions that are more closely attached to Spain as a nation. The country is presently divided into 50 provinces, which are grouped into 17 administrative regions. ${ }^{14}$ Each has a distinct history, dialect/language, culture and, accordingly, opinions when it comes to EU-related matters. ${ }^{15}$

\subsection{The Cues from the Spanish Media on the Euro}

In order to examine how the various regional dynamics play out in the public sphere and how these forces then influence public opinion patterns, it is important to look at the cues that were coming from the national media vehicles during the time period leading up the Eurobarometer 58.1 study. ${ }^{16}$

The Factiva database tool was used to examine three major national newspaper vehicles - ABC, El Mundo and El País. Due to the unique status of Catalonia in Spain, two Catalan newspapers were reviewed as well: La Vanguardia and El Periódico de Catalunya, the latter of which is available in both Spanish (Castilian) and Catalan. ${ }^{17}$

\footnotetext{
${ }^{13}$ Carlos Closa and Paul M. Heywood, Spain and the European Union (New York: Palgrave MacMillan, 2004), 33.

${ }^{14}$ These are Andalucia, Aragon, Principality of Asturias, Balearic Islands, Basque Country, Canary Islands, Cantabria, Castile-La Mancha, Castille and Leon, Catalonia, Extremadura, Galicia, La Rioja, Madrid, Region of Murcia, Foral Community of Navarre and Valencia.

${ }^{15}$ With regard to specific regions, Thomas Lancaster has found that individuals from Catalonia (Cataluña) are more likely to have defined opinions about political issues when compared to the rest of Spain, with those from Galicia being the least knowledgeable about the overall international political environment and Spain's role within it. For more on these divisions, see Lancaster, Thomas D. "Regionalism, Nationalism and State Institutions: An Assessment of Opinions in Spain." Publius 27, no. 4 (1997): 115-33.

${ }^{16}$ To be discussed in more detail in Sections 3 and 4.

${ }^{17}$ The possibility of reviewing the Basque papers was considered as well, but the difficulty in understanding the Euskera language prevented such analysis in this study. Two Basque Country papers were available in Castilian in Factiva: El Correo and El Diario Vasco. However as both publications were only launched in 2004, this did not qualify them to be evaluated during the prescribed time frame of June to November 2002.
} 
The keyword search was conducted using the headline and lead paragraph function in Factiva, which is accepted to be more precise and thus more likely to capture the most relevant articles than a subject search alone. The same process was used for the searches on both the Euro and the Eastern Enlargement. ${ }^{18}$

The articles encountered on the Euro were divided into five primary categories: those that discuss the policy of the Spanish Central Bank, prices and the state of the Spanish economy, the Euro-Dollar parity ${ }^{19}$, how the Euro is faring in other Euro-zone countries and a discussion of other EU policies. An additional "Other" category was added for all articles that were relevant to, and might influence, opinion about the Euro, but which did not fall into one of the more clearly defined groupings.

Overall, when considering all five publications, the largest group of articles centered on the state of other Euro-zone countries, followed by the Euro-Dollar parity. Although the issue of prices and the state of the Spanish economy comes in as a close third, it is interesting to note that it was consistently not the primary issue emphasized. For El País, the two largest topic groups were the prices/state of the Spanish economy and the state of other EU economies. El Mundo also focused quite a bit on other Eurozone countries, but the primary topic was the comparison of the Euro to the US Dollar. Within the two Catalan publications, there is a perceptible distinction. La Vanguardia, much like the national papers, brings more focus to the way that other countries are receiving the Euro and the manner in which the new currency appears on the international stage. El Periódico de Catalunya, on the other hand, focuses the majority of its articles on

\footnotetext{
18 The keywords that were used are "euro" and "ampliación”, respectively.

${ }^{19}$ Although most articles compared the Euro to the US Dollar, a number of comparisons to the Japanese Yen were also made.
} 
the state of the Spanish economy and the relative difference in prices since the Euro's arrival.

Although El País is generally not viewed to be as nationalistic as $A B C^{20}$, when it came to the issue of letting go of the peseta, there was a strong sense of reluctance expressed. On November 24, El País published an article that discussed the history of the peseta as the national currency, effectively acting as the final, nostalgic goodbye to the national symbol. ${ }^{21}$ Although there were a few articles published earlier in the year that formally welcomed the Euro, there is an evident expression in El País of the difficulty in parting with the national currency.

Within the Catalan publications, articles about the Euro focused more on logistics; for example issues such as having to change the way vending machines function across Spain. $^{22}$ Even though it published a few articles on how the switch affected prices in Barcelona, ${ }^{23}$ El Periódico de Catalunya had more of an eye on the positive outcomes of the introduction of the Euro and the importance of Spain being in the first wave of countries in the Euro-zone. Through this evaluation, it is evident that the main cues on the topic of the Euro are rooted in the logistical difficulty of the switch and the emotional journey of parting from the peseta as a national symbol.

\subsection{The Cues from the Spanish Media on the Eastern Enlargement}

As the Euro was introduced almost a full year prior to the collection of data of Eurobarometer 58.1, opinions on that topic, in large part, stemmed from the immediate,

\footnotetext{
20 Juan Díez Medrano, Framing Europe (Princeton: Princeton University Press, 2003), 152.

21 "La Última Pesetilla Antes Del Euro," El País November 24, 2002.

22 "Ibervending Se Recupera Del Efecto Euro," La Vanguardia, October 21, 2002.

${ }^{23}$ For example, "Un Altre Error Als Taxis," El Periódico de Catalunya, November 30, 2002.
} 
first-hard experiences with the new currency. When it came to the Eastern Enlargement on the other hand, the study was conducted two years prior to the date of the actual enlargement, which formally took place on May 1, 2004. Consequently the media pieces and opinions associated with the issue that emerged in 2002 had to do more with expectations and hopes/fears about the future rather than the situation at hand and the daily reality of the Spanish citizens.

With this in mind, in contrast to the articles/messages about the Euro coming from the papers in question, the issue of the Eastern Enlargement seemed to focus on an assessment of how other European countries were reacting, before looking inside Spain for a more local assessment of the matter. At two years prior to the actual enlargement taking place, it appears that Spanish media, much like the rest of the Spanish citizenship, was uncertain about what the consequences would be for Spain and which stance to take on the enlargement.

When evaluating the five newspapers in questions, four primary categories of articles emerge: the effects on Structural Funds and the Common Agricultural Policy (CAP), the experience of the incoming countries, economic consequences for Spain and reaction from existing EU countries.

Although structural funds are generally perceived to be at the top of concerns for the Spanish public, what is clear from the analysis here is that more than the issue of the structural funds being taken away and threats to the extensively nurtured CAP of the EU, it is the matter of immigration that was being emphasized in the time period leading up to the Eurobarometer survey in question. When it comes to the Catalan publication of $\mathrm{La}$ 
Vanguardia, there were at least three instances during which the publication released an article about the onslaught of immigration that enlargement would bring on. ${ }^{24}$

Overall, it is evident that the reason for this widespread acceptance of the enlargement is generally blind support, with most Spaniards not having sufficient information about the issues at hand and of how the enlargement would likely affect Spain. The issue of the enlargement is highly influenced by the transfer of support for both EU membership and the EMU. ${ }^{25}$

\section{Section 3: Letting go of the peseta: Spain and the Euro}

In order to have a sufficiently large sample size and a credible information source, the data consulted for this study was collected through the Eurobarometer project of the European Union. The specific survey evaluated is Eurobarometer 58.1: The Euro, European Enlargement and Financial Services, which was conducted between October and November 2002.

This particular Eurobarometer study was chosen for a number of reasons. The first was the year that the study was conducted. The intention in this analysis was to focus on a time period that captured the hopes and fears of what the future of the new currency would mean for citizens within Spain, as well as an assessment of how the Euro has tangibly touched their lives during the year it was introduced. This is a unique instance in time as it was possible to see the past, the present and future views towards the Euro all coming together in a critical moment.

\footnotetext{
${ }^{24}$ June 10, 16 and July 8. 2002.

25 This will be explored and discussed in more detail in Section 4.
} 
In evaluating opinions towards the Euro, two dependent variables are defined. The first is that of support for EMU policy. This is an important aspect of assessment as it provides the broader picture of how the Euro is viewed. In order to capture the individual-level analysis, it was important also to examine the personal level of attachment to the Euro as a currency and what it means for people on an emotional level. Thus the second dependent variable was defined as attachment to the Euro.

The four primary explanatory variables are: support for EU membership, attachment to a regional identity, attachment to Spain and perceptions of personal benefit from EU membership. The effect of these four independent variables on both of the existing dependent variables were tested using multivariate regression analysis, both logistic and OLS, as appropriate. In order to ensure that the relationship between the dependent and independent variables is nonspurious, three control variables were also included in the model. These are income, education and knowledge of the European Union.

\subsection{Support for the European Monetary Union}

Although the Spanish elite have traditionally displayed a unified front on the topic of the European Union and Spain's membership within it, “the debate on the European Monetary Union was the first symptom of an emerging elite split between those still wanting a greater transfer of sovereignty to the European Union and those content with leaving things as they currently stand." 26 Prior to the common monetary union coming into existence, EU policies generally left room for national government involvement on a

\footnotetext{
${ }^{26}$ Juan Díez Medrano, "The Public Sphere and the European Union’s Political Identity " in The Politics of European Identity Construction, ed. Peter Katzenstein and Jeffrey Checkel (Cambridge: Cambridge University Press, Forthcoming), 23.
} 
variety of levels. In many ways, the EMU took away this opportunity for Spanish elites to exercise their long-standing control over the political and economic activities of the country. ${ }^{27}$ By taking monetary and fiscal autonomy away from the member states and granting exclusive authority to the European Central Bank, the EMU presented a policy matter that could not be divided across levels of government, thereby taking away power from national elites.

Within this framework, we now turn to Table 1, below which shows the coefficient estimates that were generated using multivariate logistic regression for the dependent variable testing support for the European Monetary Union.

Table 1. Factors influencing Support for EMU as a policy choice

\begin{tabular}{|c|c|c|}
\hline \multirow{2}{*}{$\begin{array}{l}\text { Independent Variables } \\
\text { Support for EU }\end{array}$} & \multicolumn{2}{|c|}{$\begin{array}{l}\text { Dependent Variable } \\
\text { Support for EMU }\end{array}$} \\
\hline & $1.39 * * *$ & 4.03 \\
\hline Membership & $(0.22)$ & \\
\hline $\begin{array}{l}\text { Personal Advantage of } \\
\text { EU }\end{array}$ & $\begin{array}{l}0.50 * * \\
(0.20)\end{array}$ & 1.65 \\
\hline Attachment to Region & $\begin{array}{c}0.05 \\
(0.24)\end{array}$ & 1.06 \\
\hline Attachment to Spain & $\begin{array}{c}0.07 \\
(0.24)\end{array}$ & 1.07 \\
\hline EU Knowledge & $\begin{array}{c}0.09 \\
(0.09)\end{array}$ & 1.10 \\
\hline Education & $\begin{array}{l}0.09 \\
(0.05)\end{array}$ & 1.09 \\
\hline Income & $\begin{array}{l}0.12 * * \\
(0.06)\end{array}$ & 1.13 \\
\hline Constant & $\begin{array}{c}-5.55^{*} \\
(1.03)\end{array}$ & \\
\hline Pseudo $\mathrm{R}^{2}$ & 0.28 & \\
\hline $\mathrm{N}$ & 526 & \\
\hline $\begin{array}{l}\text { Standard errors appear in parenth } \\
* p<.10 ; * * p<.05 ; * * * p<.01\end{array}$ & zed figures & \\
\hline
\end{tabular}


The above-reported regression analysis shows that there is a positive and significant relationship between support for EU membership and support for the EMU. This signals that the predisposition towards supporting Spain's membership in the European Union is a reliable indicator as to whether or not a person will choose to support the European Monetary Union as a policy goal. The second independent variable illustrates that the more personal advantages an individual believes to have received from the European Union on a personal level, the more likely (s)he is to support the EMU. This is significant in terms of evaluating the economic utility hypothesis in the Spanish case. From this regression analysis, it can be inferred that, at least at the policy level, the economic considerations are weighed heavier than other factors. When it comes to the two attachment factors, national attachment emerges as being only slightly higher than that of the region. Overall, in the larger policy matter, it is the identity issue that does not resonate as much as it does in the case of the EMU. In terms of the control variables, income evolves as the strongest factor followed equally by EU knowledge and education. This ties in well with the high correlation between the personal advantage of the EU and the support of EMU as a policy.

\subsection{Attachment to the Euro}

In 2002, during the year that the Euro was introduced throughout the Euro-zone, visible regional distinctions began to emerge throughout Europe. As Robert Fishman points out, "the meaning of that shared moment for citizens of Europe was either 
national, regional or local in nature.”28 For Catalan nationalists, the Euro’s adoption was seen as an opportunity to cut the national umbilical cord to their nation, making it very much a regional issue. Due to the strong nationalistic roots within the province, the Euro was a way for the Catalan population to "break themselves from the Spanish peseta"29, a way of signalling a larger separation away from Spain as a political parent to the region.

As noted in the previous section, this was evidenced as well in El Periódico de Catalunya, which consistently expressed prices in pesetas and discussed the difficulty of switching over to the Euro. It was the regional papers that had more of a focus on the logistical and shorter-term difficulties of switching over to the Euro, while the national dailies put forth more of a larger-picture approach to place emphasis on the fact that although there is an emotional difficulty to detaching from the peseta, the economic and political advantages for both Spain and the EU in the larger sense warrants its short-term costs.

Within this understanding, the evaluation comes to the second dependent variable, that of attachment to the Euro at a more emotional level, for which OLS multivariate regression figures are listed in Table 2 below.

\footnotetext{
${ }^{28}$ Robert M. Fishman, "Identity, Social Practice and the Currency Change: Catalonia in the Year of the Euro," in The Year of the Euro: The Cultural, Social, and Political Import of Europe's Common Currency, ed. Robert M. Fishman and Anthony Messina (Notre Dame: University of Notre Dame Press, 2006), 81. ${ }^{29}$ Ibid.
} 
Table 2. Factors affecting Attachment to the Euro

\begin{tabular}{lc}
\hline Independent Variables & $\begin{array}{c}\text { Dependent Variable } \\
\text { Attachment to Euro }\end{array}$ \\
\hline Support for EU Membership & $0.23^{* * *}$ \\
& $(0.07)$ \\
Personal Advantage of EU & $0.09 *$ \\
Attachment to Region & $(0.05)$ \\
& $0.10^{*}$ \\
Attachment to Spain & $(0.06)$ \\
& $0.12^{* *}$ \\
EU Knowledge & $(0.06)$ \\
& -0.01 \\
Education & $(0.02)$ \\
& 0.01 \\
Income & $(0.01)$ \\
& $0.06 * * *$ \\
Constant & $(0.02)$ \\
& 0.38 \\
Adjusted $\mathrm{R}^{2}$ & $(0.26)$ \\
$\mathrm{N}$ & 0.12 \\
Standard errors appear in parentheses.* $p<.10 ; * * p<.05 ; * * * p<.01$ (two-tailed)
\end{tabular}

Support for EU membership is significantly and positively related to the Euro attachment variable, much like with the first dependent variable, which again emphasizes the importance of historical predispositions in setting the stage for opinion formation on specific EU policy matters. Although this initial similarity does exist between the two dependent variables, the factor of the personal advantage of the EU is not as significant once the discussion is brought down to a more emotional level. Interestingly, when the focus is on personal feelings of attachment, the more pragmatic, economic considerations become sidelined. 


\subsection{Regional Attachments}

For the purpose of this study and in order to ensure that the findings are meaningful and free of the degrees of freedom error, the original regional breakdown variable was recoded and re-grouped into geographical regions that had 30 or more observations within each category. Table 3 below shows the percentage breakdown of feelings of attachment towards the region, the European Union and the Euro in each of the major Spanish regions.

Table 3. Attachment to Region, Spain, EU and the Euro

\begin{tabular}{lcccc}
\hline \multicolumn{1}{c}{ Region } & $\begin{array}{c}\text { Attachment Attachment AttachmentAttachment } \\
\text { to Region } \\
\text { to }\end{array}$ & $\begin{array}{c}\text { Spain } \\
\text { (\%) }\end{array}$ & $\begin{array}{c}\text { European } \\
\text { the } \\
\text { Union (\%) }\end{array}$ & $\begin{array}{c}\text { (\%) Euro } \\
\mathbf{( \% )}\end{array}$ \\
\hline Catalonia & 85 & 80 & 58 & 71 \\
Basque/Navarra (North-East) & 85 & 54 & 56 & 66 \\
North & 86 & 86 & 44 & 62 \\
Canary Islands & 82 & 66 & 50 & 59 \\
Madrid & 71 & 87 & 30 & 58 \\
Galicia & 86 & 79 & 32 & 54 \\
Centre & 81 & 88 & 39 & 54 \\
East & 77 & 81 & 48 & 52 \\
Aragon, Rioja & 66 & 79 & 16 & 51 \\
Andalucia (South) & 88 & 86 & 49 & 48 \\
SPAIN & $\mathbf{8 2}$ & $\mathbf{8 1}$ & $\mathbf{5 5}$ & $\mathbf{5 7}$ \\
\hline
\end{tabular}

Prior to evaluating the relationship between attachment to the region and how it plays into connections to the EU, it is important to examine the connection between attachment to the specific region in question and Spain as a nation. At 54\%, we see the lowest attachment to Spain coming from the Basque region. Based on its history of separatism and pursuit towards disassociation from the nation, this is not a surprising 
finding. The highest level of national attachment comes from the central Madrid region, which is also to be expected as it is the political capital of Spain. What is interesting to note, however, is the relatively low level of regional attachment that is evident in the capital region. This shows that national identity is so strong in the central region that the regional attachment is minor by comparison.

Geographically, the regions that are the furthest from the centre are also most attached to their region and least attached to the capital and the nation as a whole. Turning attention to the issue of the EU, at $71 \%$ attachment to the Euro, it is evident that Catalonia is the most connected to the new currency from all regions of Spain, followed closely by the Basque Country.

Overall, even though it is clear that there are certain groups within the country that are dissatisfied with the Euro because of expectations of disruption in their daily lives, they are still the minority as there appears to be an understanding throughout the country that it is to the advantage of Spain to be part of the European Union, even if that means giving up their national currency and part of their regional identity. As long as they do not feel their strong regional roots being compromised, North Eastern regions in particular can accept further deepening of the EU and the consequences they bring for Spain.

\subsection{The Information Effect on EU Membership and EMU Opinions}

To test the limits of the political knowledge hypothesis in this study, two additional variables were created to evaluate the existence of opinion on EU membership and of the EMU as a policy. Both are dummy variables based on whether or not there was 
an answer for survey questions 12 and 26, respectively. ${ }^{30}$ The primary explanatory variable is EU Knowledge, in the same way that it appears in earlier tests in this section. The education and income control variables were also included, with the results of the logistic regression presented below in Table 4.

Table 4. Effect of EU Information on Opinion Formation

\begin{tabular}{|c|c|c|c|c|}
\hline \multirow{2}{*}{$\begin{array}{l}\text { Independent Variables } \\
\text { EU Knowledge }\end{array}$} & \multicolumn{2}{|c|}{$\begin{array}{c}\text { Dependent } \\
\text { Opinion Formation about } \\
\text { EU Membership } \\
\end{array}$} & \multicolumn{2}{|c|}{$\begin{array}{l}\text { Variables } \\
\text { Opinion Formation about } \\
\text { EMU }\end{array}$} \\
\hline & $\begin{array}{c}0.10 \\
(0.19)\end{array}$ & 1.11 & $\begin{array}{c}0.10 \\
(0.12)\end{array}$ & 1.10 \\
\hline Education & $\begin{array}{l}0.58^{*} \\
(0.31)\end{array}$ & 1.79 & $\begin{array}{l}0.15^{*} \\
(0.08)\end{array}$ & 1.17 \\
\hline Income & $\begin{array}{c}0.09 \\
(0.10)\end{array}$ & 1.09 & $\begin{array}{c}-0.02 \\
(0.08)\end{array}$ & 0.98 \\
\hline Constant & $\begin{array}{l}1.43^{*} \\
(0.89)\end{array}$ & & $\begin{array}{l}2.36 * * * \\
(0.69)\end{array}$ & \\
\hline Pseudo $\mathrm{R}^{2}$ & 0.14 & & 0.03 & \\
\hline $\mathrm{N}$ & 589 & & 589 & \\
\hline
\end{tabular}

What is evident from the above figures is that the EU Knowledge variable has the same effect on opinion formation about EU membership in the larger sense and the European Monetary Union more specifically. The education factor, which was notably absent when evaluating its impact on support for the EMU, becomes significant when testing solely for opinion formation. Consequently, people who are more educated are more likely to hold a defined opinion about Spain’s membership in the European Union.

As the second part of Table 4 illustrates, education also has a positive and significant effect on opinion formation about the common currency. This shows that longer-term predispositions may actually be more important here than short-term

${ }^{30}$ Q26, phrase 1 that references the common currency. 
information effects. Moreover, as the effect of the information variable is not statistically significant, it can be concluded that it is unlikely to affect opinion formation for the particular issues of EU membership and the EMU.

\section{Section 4: Spain and the Enlargement}

To evaluate the way in which these factors play into opinions of the general Spanish public, logistic multivariate regressions were conducted to uncover the factors that impact the dependent variable of support towards Enlargement.

Additionally, there were four other explanatory variables which addressed issues associated with the Eastern Enlargement specifically. The first of these addresses the potential shift in Spain's position within Europe after the new countries are added into the

Union. The second factor is the way in which unemployment rates within the country would be affected after the new incoming countries joined the European Union. The third variable that was tested is that of the effect on the EU funds directed towards Spain. The final factor that was evaluated in the framework of the Eastern Enlargement is the consequence for Europe's position on the world stage. 


\subsection{Support for the Eastern Enlargement}

Due to the fact that the dependent variable is dichotomous, logistic regression methods were employed to estimate the effect of the independent variables on support for the enlargement. The coefficients from the multivariate regression are listed below in Table 5.

Table 5. Factors influencing Support for Enlargement

\begin{tabular}{|c|c|c|}
\hline \multirow{2}{*}{$\begin{array}{l}\text { Independent Variables } \\
\text { Support for EMU }\end{array}$} & \multicolumn{2}{|c|}{$\begin{array}{c}\text { Dependent Variable } \\
\text { Support for Enlargement }\end{array}$} \\
\hline & $\begin{array}{l}1.40 * * * \\
(0.50)\end{array}$ & 4.05 \\
\hline $\begin{array}{l}\text { Effect on Spain's } \\
\text { importance in Europe }\end{array}$ & $\begin{array}{l}-1.16^{* *} \\
(0.47)\end{array}$ & 0.31 \\
\hline $\begin{array}{l}\text { Effect on Spain’s } \\
\text { unemployment rate }\end{array}$ & $\begin{array}{l}-1.30 * * * \\
(0.48)\end{array}$ & 0.27 \\
\hline $\begin{array}{l}\text { Effect on EU funds for } \\
\text { Spain }\end{array}$ & $\begin{array}{l}-0.16 \\
(0.48)\end{array}$ & 0.85 \\
\hline $\begin{array}{l}\text { Effect on Europe's world } \\
\text { position }\end{array}$ & $\begin{array}{l}0.95 * * \\
(0.45)\end{array}$ & 2.59 \\
\hline Enlargement Information & $\begin{array}{l}0.58^{*} \\
(0.32)\end{array}$ & 1.79 \\
\hline EU Knowledge & $\begin{aligned}-0.06 \\
(0.12)\end{aligned}$ & 0.94 \\
\hline Education & $\begin{array}{l}0.14^{* *} \\
(0.07)\end{array}$ & 1.15 \\
\hline Income & $\begin{array}{c}0.01 \\
(0.08)\end{array}$ & 1.01 \\
\hline Constant & $\begin{array}{l}-0.27 \\
(0.99)\end{array}$ & \\
\hline $\begin{array}{l}\text { Pseudo } \mathrm{R}^{2} \\
\mathrm{~N}\end{array}$ & $\begin{array}{l}0.30 \\
296^{31}\end{array}$ & \\
\hline
\end{tabular}

\footnotetext{
31 The reason for the lower $\mathrm{N}$ in this model has to do with the fact that four of the independent variables originate from the same survey question (Question 43), which had a higher level of missing answers than the explanatory variables in Section 3. The missing data figures on these answers range from 159 (world importance variable) to 249 (unemployment variable). This in itself is significant in exemplifying the high level of confusion on the consequences of the enlargement, with so many people choosing to abstain from answering rather than take a stance on concrete outcomes of this policy.
} 
Even though there are a number of independent variables that show a significant correlation to the dependent variable, the strongest relationship is with that of support for the common European monetary policy. This shows that individuals who support the EMU are significantly more likely to support the Eastern Enlargement as well.

When reviewing the independent variables measuring effect of the enlargement on Spain's situation within Europe, there is a strong relationship between those people who believe that Spain will lose its position within the European Union after the Eastern Enlargement and those that do not support the Enlargement at all. The variable associated with Europe's position within the world shows an equally strong relationship to the dependent variable, in essence emphasizing the importance of the larger understanding that there are greater benefits to implementing the proposed EU policies, both about the Euro and the Eastern Enlargement for the benefit of Spain within Europe and for Europe within the world.

The factor related to unemployment rates also exhibits a significant relationship with the dependent variable. This issue is closely tied to the larger immigration framework for Spanish citizens as an inflow of new immigrants could equal the loss of jobs. Although the issue of the structural funds displays some influence, this variable does not show up in this model to be as strong of a factor in determining whether or not there is support for the enlargement. Those that agree that Spain will receive less funds after the enlargement are less likely to support it, but not greatly so. The relationship is much less significant compared with the other independent variables and thus dispels a great deal of the expected fears and emphasis on the funding issue that was believed to have extensively framed Spain’s understanding of its role within the European Union. 
The question about EU's overall position in the world and how it is affected by the enlargement surfaces as a significant factor here. Those people that agree with the fact that widening the EU will grant the region a greater position on the world sphere are also more likely to be supportive of the enlargement, by a large degree.

In this evaluation, the media cues are clearly coming through as influences, but in an unexpected way. In fact, it appears as though it is actually the messages coming through about the Euro that are having more of an effect here than those about the enlargement. As noted in Section 2, the media messages about the Euro were much more defined than those about the Eastern Enlargement. A large group of the articles that were published in 2002 were focused on the Euro/Dollar parity, essentially as a symbol for the way in which the EU is perceived internationally. These messages appear to work together with pre-existing dispositions related to the EU in the larger sense, which is helping individuals assess the larger benefits of EU initiatives, whether they were targeted towards a vertical or horizontal expansion of the European Union.

This finding once again emphasizes the potential effects of Euro information on opinions being formulated about the enlargement because Spanish citizens feel that they are much better informed about other EU issues. Although they do not exert as strong of an effect on the dependent variable, the EU Knowledge and education variables do prove to be statistically significant, showing some evidence for the cognitive mobilization theory in this model. 


\subsection{Attachment and the Enlargement}

As there is a perceptible relationship between regional attachment and attachment towards the Euro as presented in the previous section, it is important to review the same attachment factor in the case of the Eastern Enlargement. Due to the fact that it is not possible to create a variable that represents attachment to the Eastern Enlargement as it is an abstract concept, the dependent variable is defined as support for the enlargement, while the independent variables of attachment to the region, Spain and the EU are presented in the same way as they appear in Section 3. The logistic regression coefficients are presented in Table 6 below.

Table 6. Attachment and Support for Enlargement

\begin{tabular}{|c|c|c|}
\hline Independent Variables & $\begin{array}{l}\text { Dependent } \\
\text { Support for Er }\end{array}$ & \\
\hline Attachment to Region & $\begin{array}{l}-0.08 \\
(0.15)\end{array}$ & 0.92 \\
\hline Attachment to Spain & $\begin{array}{l}-0.41^{* * * *} \\
(0.15)\end{array}$ & 0.66 \\
\hline Attachment to the EU & $\begin{array}{l}1.22 * * * \\
(0.14)\end{array}$ & 3.38 \\
\hline Constant & $\begin{array}{l}0.33^{*} \\
(0.43)\end{array}$ & \\
\hline Pseudo $\mathrm{R}^{2}$ & 0.13 & \\
\hline $\mathrm{N}$ & 776 & \\
\hline
\end{tabular}

What is noticeable from the above figures is that there is a very strong and significant relationship between attachment to the European Union and support for the Eastern Enlargement. Those people who are attached to the European Union are also much more likely to support the enlargement. This is likely to surface some of the 
longer-held feelings related to the EU in the understanding that the enlargement will benefit the EU overall.

Reviewing national influences, attachment to Spain exhibits about half as strong of an impact on whether or not an individual would support the enlargement. The relationship is negative, which illustrates that those people who are more attached to Spain as a nation are less likely to support the enlargement. This brings forth some of the nationalistic beliefs and predispositions related to immigration and how it could affect Spanish identity.

\subsection{The Information Effect on Enlargement Opinions}

Although knowledge about the EU does not have a significant effect on Spanish citizens supporting the enlargement, there remains a larger question about whether or not information actually helps to formulate an opinion at all. ${ }^{32}$

The first independent variable is that of EU Knowledge. The variable of information about the Enlargement was added, as well as education and income as control factors. ${ }^{33}$ The coefficient estimates from the logistic regression analysis are presented in Table 7 below.

\footnotetext{
${ }^{32}$ In order to get at this factor, responses to Question 26 were used in order to create a dichotomous variable that would represent opinion formation when it came to the enlargement. If there was an answer provided to the enlargement phrase in Question 26, it was coded as 1. All "don't know" or missing answers were coded as 0 .

${ }^{33}$ Although there may appear to be multicolinearity between the EU Knowledge and Enlargement Information variables, the correlation figure is only 0.50 . The VIF figures for the model range between 1.25 and 1.44 - low enough to conclude that multicolinearity is not a concern here.
} 
Table 7. Effect of EU and Enlargement Information on Opinion Formation

\begin{tabular}{|c|c|c|}
\hline \multirow[t]{2}{*}{ Independent Variables } & \multicolumn{2}{|c|}{$\begin{array}{c}\text { Dependent Variable } \\
\text { Opinion Formation about the Eastern } \\
\text { Enlargement }\end{array}$} \\
\hline & $0.21 * * *$ & 1.23 \\
\hline \multirow[t]{2}{*}{ EU Knowledge } & $(0.07)$ & \\
\hline & 0.06 & 1.06 \\
\hline \multirow[t]{2}{*}{ Enlargement Information } & $(0.18)$ & \\
\hline & 0.03 & 1.03 \\
\hline \multirow[t]{2}{*}{ Education } & $(0.04)$ & \\
\hline & 0.04 & 1.04 \\
\hline \multirow[t]{2}{*}{ Income } & $(0.04)$ & \\
\hline & 0.26 & \\
\hline Constant & $(0.83)$ & \\
\hline Pseudo $\mathrm{R}^{2}$ & 0.04 & \\
\hline $\mathrm{N}$ & 579 & \\
\hline
\end{tabular}

According to the figures above, it is apparent that EU Knowledge does have a significant effect on whether or not there will be opinion formulation on the matter of the Eastern Enlargement, in a way that is stronger than for the issues of EU membership and the EMU. This illustrates that people who have more knowledge about the EU in the larger sense are more likely to form a defined opinion about the Eastern Enlargement than those that have no information at all. Moreover, EU Knowledge clearly outweighs enlargement information when it comes to opinion formation about the enlargement. This reaffirms the fact that as there weren't clear messages about this issue coming through the daily media, the Spanish public relied more on the larger issue of the EU to form opinions on the matter. Moreover, the more salient subject of the Euro dominated media 
coverage during this time period and provided a clearer symbol and touchstone from which to formulate opinions.

\section{Discussion and Conclusions}

In the form of a new currency, the Euro brought with it a common European symbol that had never existed before. The Euro possesses something that other social symbols do not: an economic and political purpose that at its core has the underlying reasons for unification - those of becoming a unified power to rival the United States on the international stage. From this study, it is evident that in the Spanish case, this common goal and the country’s long-held interest of being accepted as a member of the exclusive Western European club, outweighs any inconveniences that it may have initially encountered. While the common European currency completed the economic unification goals of the Union, the Eastern Enlargement has been the catalyst in unifying the continent geographically and bridging the long-held cultural divides that have existed between the two main regions of Europe. Historically, there have been ongoing conflicts, both economic and political in nature, that have defined the way in which Eastern Europeans and Western Europeans approach one another.

In terms of the Eastern Enlargement, the overall perception of the consequences of this EU policy for Spain was not as clear from the media analysis. Many of these messages reappeared within opinion groupings when the regression analysis was conducted. In terms of the Euro, what becomes clear is that support for EU membership predisposes individuals to support the EMU as a policy as well. Moreover, the personal advantage factor plays a large role in weighing out the pros and cons of accepting the 
new currency. In this broader perspective, economic factors play a large role. When considering the issue at an emotional level, however, a different picture emerges. Although predisposition towards EU membership is still a large factor, regional and national attachments also play an important role in influencing attachment towards the Euro.

With regards to the Eastern Enlargement, the same vagueness and uncertainty evident in the media evaluation came through in the way opinions on this issue were formed. Much of the understanding of the enlargement was based on previous evaluations of the EU in the larger sense and, more specifically, the Euro. ${ }^{34}$ Overall, in terms of the enlargement, despite the confusion, there was consensus on the fact that the enlargement weighed heavily on the way in which Spain's present role and overall position in Europe would shift in the future after the new countries officially entered the Union.

While education was a significant factor for determining whether or not there would be opinions formed about the EMU, it evolved as the strongest determinant of opinion formation about EU membership. This may be due to the fact that knowledge and information about the EU have been integrated into the education system, while the EMU is still a fairly fresh concept that has existed in the media, but one that has not yet been integrated into the education curricula. ${ }^{35}$

\footnotetext{
${ }^{34}$ It is important to note that much of this had to do with the fact that media analysis and survey questions were evaluated in 2002, during the year that the Euro was introduced.

${ }^{35}$ To that end, it would be interesting to expand this study into an evaluation of the way in which the EU appears in the education system and the way that both the EMU and the Eastern Enlargement would be integrated into formal study at various levels. This would be an especially intriguing issue to explore after the completion of the Bologna Process, which aims to regulate and unify education systems across the European continent.
} 
From this analysis, it is possible to conclude that both predisposition and political symbols come into play when Spanish citizens evaluate the way in which widening and deepening of the European Union will affect them on a personal level and how it will play out in the future. As people, we need a foundation, something to build from in order to have room to define our own individual opinions on a particular issue. This study illustrates that reference groups in the form of the media, regional influences and national elites all factor in and co-exist with utilitarian considerations and emotional attachments to the symbols that define our individual identities.

\section{Bibliography}

Closa, Carlos , and Paul M. Heywood. Spain and the European Union. New York: Palgrave MacMillan, 2004.

Converse, Philip E. "The Nature of Belief Systems in Mass Publics." In Ideology and Discontent, edited by David E. Apter. New York: The Free Press, 1964.

Díez Medrano, Juan. "Democracy, Legitimacy and the European Union." In A European Public Sphere: How much of it do we have and how much do we need? \$Amsterdam: Network of Excellence CONNEX and The Amsterdam School of Communications Research ASCoR, 2005.

- Framing Europe. Princeton: Princeton University Press, 2003.

— . "The Public Sphere and the European Union’s Political Identity " In The Politics of European Identity Construction, edited by Peter Katzenstein and Jeffrey Checkel. Cambridge: Cambridge University Press, Forthcoming.

Fishman, Robert M. "Identity, Social Practice and the Currency Change: Catalonia in the Year of the Euro." In The Year of the Euro: The Cultural, Social, and Political Import of Europe's Common Currency, edited by Robert M. Fishman and Anthony Messina, 81-96. Notre Dame: University of Notre Dame Press, 2006.

Hechter, Michael. "A Theory of Group Solidarity." In The Microfoundations of Macrosociology, edited by Michael Hechter, 16-55. Philadelphia: Temple University Press, 1983. 
"Ibervending Se Recupera Del Efecto Euro." La Vanguardia, October 21, 2002.

Inglehart, Ronald, and Jacques-Rene Rabier. "Economic Uncertainty and European Solidarity: Public Opinion Trends." Annals of the American Academy of Political and Social Science 440, no. Nov. 1978 (1978): 66-97.

"La Última Pesetilla Antes Del Euro." El País November 24, 2002.

Lippmann, Walter. Public Opinion. New York: The MacMillan Company, 1922.

Mahler, Vincent A., Bruce J. Taylor, and Jennifer R. Wozniak. "Economics and Public Support for the European Union: An Analysis at the National, Regional and Individual Levels." Polity 32, no. 3 (2000): 429-53.

McLaren, Lauren M. . Identity, Interests and Attitudes to European Integration. New York: Palgrave MacMillan, 2006.

Niedermayer, Oskar, and Richard Sinnott, eds. Public Opinion and Internationalized Governance. New York: Oxford University Press, 1995.

"Un Altre Error Als Taxis." El Periódico de Catalunya, November 30, 2002.

Zaller, John. The Nature and Origins of Mass Opinion. Cambridge: Cambridge University Press, 1992. 